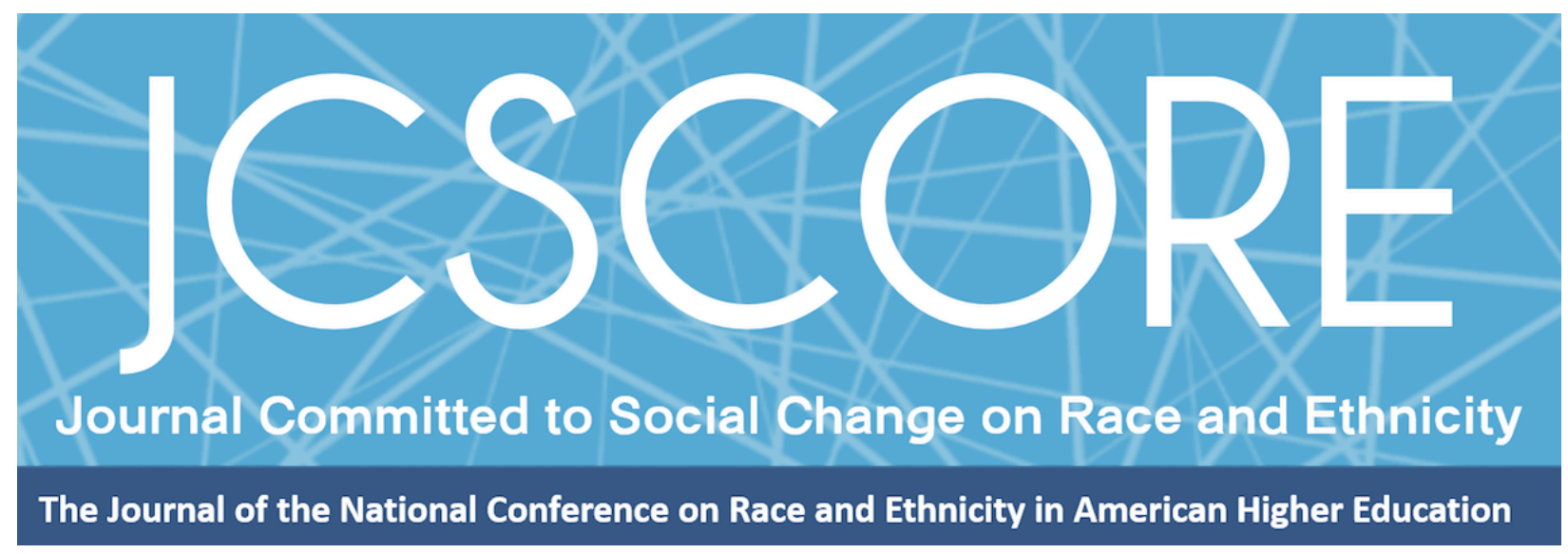

\title{
BUILDING INDIVIDUAL AND INSTITUTIONAL CAPACITY OF AN URBAN ACADEMIC HEALTH SYSTEM TO SERVE LOCAL SEX TRAFFICKING VICTIMS
}

\author{
Jann Murray-Garcia \\ University of California Davis \\ Kupiri W. Ackerman-Barger \\ University of California Davis \\ Ellen Goldstein \\ University of Wisconsin, Madison \\ Jerry John Nutor \\ Drexel University
}

Journal Committed to Social Change on Race and Ethnicity Volume 3, Issue 2 | 2017

Copyright $(2017$ Board of Regents of The University of Oklahoma on behalf of the Southwest Center for Human Relations Studies.

Permission of the Publisher is required for resale or distribution and for all derivative works, including compilations and translations. Quoting small sections of text is allowed as long as there is appropriate attribution. 


\title{
Building Individual and Institutional Capacity of an Urban Academic Health System to Serve Local Sex Trafficking Victims
}

\author{
Jann Murray-Garcia \\ University of California Davis \\ Kupiri W. Ackerman-Barger \\ University of California Davis \\ Ellen Goldstein \\ University of Wisconsin, Madison \\ Jerry John Nutor \\ Drexel University
}

\begin{abstract}
Every day, there are unrecognized sex trafficked victims visiting urban academic health systems in the United State, victims who are perhaps hoping against hope that a frontline provider, student, or staff member would ask that one question that would identify them as enslaved or otherwise trapped in an unthinkable situation. Health care providers' lack of awareness of the relatively hidden population of sex trafficked victims causes missed opportunities to improve public health. Training healthcare providers to recognize and serve sex trafficked victims is critical, but such training will likely be less effective without addressing the institutional capacity of urban academic health systems. Indeed, local sex trafficking industries can thrive in the shadow of urban health systems, many associated with world class universities. This exploratory study aimed to assess and enhance the institutional capacity of an urban academic health system in the United States, and that of its employees, to appropriately serve victims of sex trafficking.
\end{abstract}

Sex trafficking is a priority public health issue because of the immediacy of physical and mental health risks and outcomes faced by the victims (Baldwin, Eisenman, Sayles, Ryan, \& Chuang, 2011; Dovydaitis, 2010; Gajic-Veljanoski \& Stewart, 2007; Hossain, 2010). Sex trafficking occurs when "...a commercial sex act is induced by force, fraud or coercion, or when the person induced to perform such an act 
Journal Committed to Social Change on Race and Ethnicity | 2017

has not attained 18 years of age" (United States Department of State, 2014). Until recently, it has been relatively easy in the United States to dismiss human trafficking, and especially sex trafficking, as a phenomenon of third world countries, as something that "happens over there." On the contrary, the existence of sex trafficking activities in the United States, one of the richest country in the world, is a widespread and lucrative phenomenon, despite this nation's well-developed federal and local law enforcement systems, and its arguably undeserved reputation for progressive women's rights initiatives (Banks \& Kyckelhahn, 2011; Harris, 2012; United Nations News Centre, 2015; United States Department of State, 2014; United States Department of Education, 2013; United States Department of Justice, 2011).

According to the United States Department of Justice (2011), most suspected incidents of human trafficking are classified as sex trafficking (82\%). Of the federally funded cases opened in 2010 to investigate incidents of sex trafficking, 1,200 (48\%) were allegations for adult sex trafficking, and 1,000 (40\%) were allegations of sexual exploitation of a child (United States Department of State, 2014). According to the United States Department of Justice (2011), sex trafficking victims are overwhelmingly female and poor. Four-fifths of victims in confirmed sex trafficking incidents were identified as United States citizens (83\%) (United States Department of State, 2014). Nationally, confirmed sex trafficking victims are disproportionately Black (40\%) (Banks \& Kyckelkahn, 2011; United States Department of Justice, 2011).

The scope of child victims of sex trafficking in the United States has not been extensively researched. The United States Department of Justice's Human Trafficking Reporting System estimates that as many as 100,000 domestic minors may be involved 
Journal Committed to Social Change on Race and Ethnicity | 2017

in sex trafficking (Banks \& Kyckelkahn, 2011). The average age of sex trafficking recruitment is 11 to 14 years of age (Harris, 2012; Hom, 2013). In the United States, a substantial portion of sex trafficked victims are children who are runaways or from the foster care system, and from families where they experienced physical abuse, sexual abuse, and addiction (Ahn et al., 2013; Gajic-Veljanoski \& Stewart, 2007). It is important to note, however, that recruitment of sex trafficked victims in the United States also occurs in the nation's suburbs and on school campuses (Harris, 2012; United States Department of Education, 2013, 2012).

It is increasingly recognized that local sex trafficking industries can thrive in the shadow of urban health systems; in our case within blocks of the University of California Davis Health System (UCDHS)—located in California's capitol city of Sacramento with an approximate population of 485,000 (Syphax, 2012; Taft, 2014; United States Census Bureau, 2015). Sacramento is considered a hub of sex trafficking activities in the United States because Interstate Highway 5, which goes from the Mexican border to the Canadian border, intersects with Interstate Highway 80, which begins in San Francisco and ends on the East Coast. (Syphax, 2012; Taft, 2014). This, in addition to Sacramento's proximity to Las Vegas, means that even on the boulevard where UCDHS is located, minor and adult slaves of sex traffickers are daily being coercively and forcefully exploited. It is sobering to think that our lack of awareness of this invisible population has perhaps meant missed opportunities to improve both the health of individuals, including minors, and population health (Clause \& Lawler, 2013; Dovydaitis, 2010). 
Frontline health care professionals are often the first human service professionals to come into contact with sex trafficked victims before they have been identified as such (Baldwin et al., 2011; Gajic-Veljanoski \& Stewart, 2007). Research suggests that up to half of sex trafficking victims in the United States have had contact with a physician or other health care provider during their capture (Baldwin et al., 2011; Barrows \& Finger, 2008; Dovydaitis, 2010). In fact, health care professionals may be the only adults that victims are allowed to be with alone without traffickers or their accomplices. This presents a unique opportunity for health care providers to recognize their plight and perhaps assist these patients or possible victims (Dovydaitis, 2010).

Victims of sex trafficking have various and unique health care needs that can serve as clues for providers to investigate further by asking more specific questions (Dovydaitis, 2010; Gajic-Veljanoski \& Stewart, 2007). These health concerns include unwanted pregnancies, abortion requests, sexually transmitted infections, substance abuse, addiction and overdose, physical trauma including rape and beatings, and HIVIAIDS (Hossain, 2010). Post-traumatic stress, depression, anxiety, and suicide attempts are common (Hom, 2013; Hossain, 2010). Health care professionals may or may not recognize sex trafficking victims, including minors, in emergency rooms or reproductive health clinics (Baldwin et al., 2011; Barrows \& Fingers, 2008; Zimmerman et al., 2008). Moreover, victims of sex trafficking may have limited access to health services and be reluctant to disclose the truth and extent of their situation due to shame, helplessness, language barriers, accompanying traffickers, fear of physical injury or deportation, and clinicians' real or perceived disdain (Baldwin et al., 2011). Most health professionals have limited awareness of and education regarding how to appropriately 
Journal Committed to Social Change on Race and Ethnicity | 2017

respond to victims of sex trafficking (Ahn et al., 2013; Baldwin et al., 2011; Grace et al., 2014a; Grace et al., 2014b).

An interprofessional health care workforce that is aware of the health impact of sex trafficking, and trained to compassionately interact with individuals in a culturallyaware and trauma-sensitive manner will be able to provide optimal health care, adequate support, and appropriate referrals on behalf of this extremely vulnerable patient group. In addition, those health care professionals will be better equipped to effectively collaborate with law enforcement, case management, and advocacy partners (Ahn et al., 2013; Gajic-Veljanoski \& Stewart, 2007).

In fact, mandates for and reports of curricula and training models for individual practitioners have emerged, although further research is needed to track the impact of sex trafficking training, education, and resources on the long-term attitudinal and clinical practices of practitioners over time, in addition to the clinical and life outcomes of patients (Ahn et al., 2013; Diaz, Clayton \& Simon, 2014; Grace et al., 2014a; Grace et al., 2014b). There are well-meaning yet misguided actions that health care professionals take that can re-traumatize and place victims at greater risk during and following their clinical care. Institutional policies and procedures can also do harm, without the informed partnership of local community advocates and entities.

Perhaps as important as a trained practitioner, or even an interprofessional team of trained practitioners, is the institutional capacity required to support their clinical efforts and even augment those efforts by weighing in on municipal and regional policy levels (Murray-García \& García, 2008). UCDHS is the third largest employer in Sacramento and one of the largest employers in the greater Sacramento metro region. 
As an academic health system and training center, the geographic area from which UCDHS' patients are drawn is the size of the state of New York, extending from California's Central Valley east to the Nevada border, and north to the Oregon border. UCDHS has the potential to develop its institutional leadership and voice to weigh in locally on interagency efforts and policies that facilitate the identification and healing of the region's sex trafficked victims ("About the Health System", 2015).

As an initial step, we sought to explore how UCDHS health care providers, in the context of institutional support and potential leadership, and in conjunction with community members and other invested community institutions, could practically serve as a powerful, positive, health-giving force to this population of patients. Our goal was to assess and build the capacities of individual health care practitioners, as well as the institutional capacity of UCDHS, including introducing employees to local community advocates and experts who are dedicated to sex trafficking prevention, identification, and treatment. A four-hour workshop was developed in close partnership with community experts in this area. The extended workshop was open to any member of the UCDHS community, including health care professionals, staff, faculty, and health professions students (i.e., public health, medical, and graduate-level nursing students). We captured the experience in convening this group by evaluating the process and impact of the extended training on participants. We measured participants' pre- and post-workshop self-assessments of their awareness and knowledge about sex trafficked victims, their ability to identify and provide clinical care to sex trafficked victims, and the level of their advocacy on behalf of victims. In doing so, we hope to contribute to literature such that it can be used by other urban academic health centers to educate 
healthcare professionals, and to increase their institutional capacities to serve the hundreds of thousands of children and adults who are sex trafficked across the nation. As urban areas in the United States are disproportionately non-White, we can reasonably expect that addressing the phenomenon of sex trafficking in the proximity of urban academic health centers will address health disparities by race as well (Squires \& Kubrin, 2006)

\section{Methods}

The workshop, "Educating UCDHS Healthcare Providers to Identify and Heal Victims of Sacramento's Sex trafficking," aimed to increase knowledge, ability, and selfefficacy of health care providers to proactively identify and heal victims of sex trafficking. Bandura (1995) defined self-efficacy as belief in what an individual can do and accomplish. Individuals' perceptions of potential outcomes impact whether they will act, and to the degree to which they will persevere in the face of adversity. Closely related to the concept of self-efficacy is the concept of collective efficacy. Bandura (1995) stated,

In getting things done collectively, perceived efficacy is concerned with people's beliefs in the joint capabilities to make health promotion a national priority, to forge divergent self-interests into a shared agenda, to enlist supporters and resources for collective action, to devise effective strategies and to execute them successfully, and to withstand forcible oppositions and setbacks. (p. 33)

Bandura emphasizes that collective efficacy influences how much effort an individual will put toward change. The structure of the workshop sought to promote collective efficacy by featuring presentations from local non-profit community organizations, mental health providers, and law enforcement who are actively working to mitigate sex trafficking and to ameliorate the impact it has on the lives of individuals. The workshop was intended to provide specific information to healthcare providers as one aim. We 
Journal Committed to Social Change on Race and Ethnicity | 2017

invited community members, advocates, and healthcare consumers to brainstorm together and to build relationships in a collective effort to create joint structures, practices, and resources that could help and heal victims of sex trafficking in the Sacramento area.

Another critical aspect of developing collective advocacy, in addition to strengthening and creating links to community entities, was to identify and to enhance the institutional capacity of UCDHS. Specifically, motivated and skilled clinicians must believe they have institutional backup and support for their individual actions in support of sex trafficked victims. The workshop aimed to serve this purpose, by illustrating to future clinical advocates that their institution shared their values and sense of urgency for this patient population, that they were not alone in their intended actions, and that they would have the support of the institution both in resources and established community working relationships. It was through this sense of collective efficacy that this study sought to increase institutional capacity to serve victims of sex trafficking.

\section{Participants}

This study was approved by the UC Davis Institutional Review Board.

Participants were recruited via flyers posted at clinician work stations, announcements in the health systems intranet newsletter, email and Facebook announcements, and word of mouth. Participants included employees, or trainees of UCDHS as well as community members. Community members included a parole officer and community activists from up to 90 miles away. In their RSVP, participants were asked to make a written commitment to stay the entire four hours. We explained the risk in attending only a portion of the presentation, which included attaining just enough information and 
undirected passion to potentially compromise the emotional and physical safety of sex trafficked victims. Participants were asked to consider being part of a formal evaluation of the event by completing pre- and post-event written surveys. Approval from the UC Davis Institutional Review Board was obtained prior to the workshop, and consent was obtained through a question on the pre-survey.

\section{Training Session}

The free session was held on a weekday from 4-8 p.m.; snacks and dinner were included. Food costs and speaker honoraria were funded by the Betty Irene Moore School of Nursing, the Department of Emergency Medicine of the School of Medicine, and the UCDHS Office of Diversity and Inclusion.

Speakers from the Sacramento community made up the bulk of the training. First, Nathan Kupperman, MD, Director of the Emergency Department and Chair of the Department of Emergency Medicine, affirmed the existence of this patient population, and its unique concerns and challenges as valid and emergent for UCDHS clinicians and staff. Next, Margaux Helm, MFT, Director of WEAVE, Inc. (Women Escaping A Violent Environment) (2015) outlined the emergency and case management services provided by WEAVE to victims of domestic violence and sexual assault, including trafficked victims. She gave a detailed overview of sex trafficking in particular, including clues to identifying the sex trafficked victim; physical and mental health concerns of this patient population; factors that keep victims from disclosing to health care providers; messages that victims must hear from us as health care providers (i.e., "I believe you" and "It's not your fault"); mandatory reporting requirements; and local and national resources for victims and their health care providers. 
The second hour highlighted the poignant and powerful personal story of Leah Albright-Byrd (Bridget's Dream, 2015), a national and international speaker, law enforcement consultant, and former victim of the Sacramento sex trafficking industry. Ms. Albright-Byrd, a mixed-race African American/White woman, described how UCDHS clinicians had missed opportunities to identify and rescue her as a sex trafficking victim a decade ago, when she was an adolescent patient on the UCDHS pediatric ward. She assured us that hers was not an uncommon story throughout the nation's urban academic health care training centers. She challenged our use of the term "child prostitute", explaining that "Minors cannot be prostitutes; they can only be rape victims." Of the local sex trafficked population in the Sacramento metro area, Ms. Albright-Byrd declared, "You have to try not to see this stuff."

Following Ms. Albright-Byrd was the law enforcement official she recommended, Detective John Sydow with the Sacramento Sheriff's Department, and a member of the Federal Bureau of Investigation's Child Exploitation Task Force. He spoke of the national ideological change in seeing women and minors trafficked for commercial sex as victims and not as criminals. For instance, low level drug possession and other relatively minor offenses could be seen as symptoms of a trafficked victim, including how pimps force women into drug dependency by getting them addicted to a drug supply that the pimps ultimately control. Detective Sydow shared that his greatest challenge in executing his charge had to be the variability in individual officers' actions and attitudes regarding trafficked individuals.

These three community-based local experts, along with other community advocates who were in the audience, evidenced the support, resources, and willing, if 
under-resourced partners that exist in the community that UCDHS employees and students can access on behalf of their patients. Having these three local experts come to our health system campus reflected the intentional process of building individual and institutional capacity in addition to gaining valuable knowledge through the specific content of their presentations.

The importance of including training in implicit bias in service provision and historical distrust with health, social, and law enforcement institutions cannot be overstated (Murray-García \& García, 2008; Tervalon \& Murray-García, 1998). However, we did not specifically address those elements in this already extended, introductory training.

\section{Evaluation Tool}

Pre- and post-workshop surveys were administered. Survey questions with a five-point Likert scale were administered only to participants who identified as health professionals, or health professions students to ascertain their pre-workshop levels of self-assessed knowledge, ability, and self-efficacy, as well as post-workshop perceived increases, if any, in knowledge, ability, and self-efficacy (see Appendix B). A preworkshop question was asked of all participants regarding the participant's present level of awareness and advocacy on behalf of local victims. A post-workshop question sought the participant's awareness of and active advocacy on behalf of local sex trafficked victims (see Appendix C). A single question asked if participants believed UCDHS had the institutional capacity to appropriately serve local sex trafficked victims. Open-ended questions were utilized to assess in what ways, if at all, participants felt the workshop equipped them to serve sex trafficked patients; what further training, resources, and 
tools they needed; and what further tools or resources UCDHS needed as an organization to provide the highest quality care to victims of sex trafficking. Finally, participants were asked to imagine and list other roles that UCDHS could play in eliminating the sex trafficked industry in Sacramento, and to provide optimal care for victims and survivors of sex trafficking.

Finally, an open-ended dialogue and brainstorming session was conducted during the workshop, from which additional data regarding participants' perceptions, challenges, and experiences were gathered. Potential solutions to these challenges were also recorded by a designated scribe. This dialogue and brainstorming session was designed to generate data. The session was also used to demonstrate the value, necessity, and existing potential of interprofessional, ongoing, dynamic dialogue among institutional members and community advocates and members, to build individual, institutional, and regional capacity.

\section{Measures and Analysis}

Frequencies were calculated to show the distribution of participant characteristics, and for health providers to compare pre- and post-survey responses. Data were analyzed using descriptive inferential statistics by determining the mean, standard error, and standard deviations using SPSS version 21.

A Likert-type pre-workshop question was used to demonstrate healthcare providers' self-assessments of their awareness, knowledge, skills and confidence. The post-workshop self-assessment questions asked participants to what degree they agreed, or disagreed that they had increased in that paired dimension (see Appendix B). Tests of statistical significance were not appropriate here. 
All participants indicated pre-workshop to what extent they were aware of Sacramento's sex trafficking phenomenon, and to what extent they were involved as active advocates (see Appendix C). We re-categorized those who chose option \#4 or \#5 as "Active Advocates," and derived the sums and the percentages for the following groups: 1) all participants, and 2) healthcare providers and students, whether or not they were employed by UCDHS. We compared this summed percentage with the percentage of participants who "agreed" or "strongly agreed" to a post-workshop response to the single statement — "I plan to become an active advocate against sex trafficking." Chi-square analysis was used to compare pre- and post-workshop percentages.

\section{Thematic Analysis}

Thematic analysis was used to code all participants' responses to open-ended questions, to gain insight into the broader patterns, and to interpret phenomena across the data (Boyatzis, 1998). Themes that emerged from participant responses were labeled systematically. Responses of a similar genre were color coded and categorized under a common label that captured the meaning expressed in one or more original themes. Labels were inductively derived as well as generated a priori based on a review of the literature.

\section{Results}

The event was attended by 76 participants, excluding workshop organizers, and 67 (88\% response rate) completed the pre- and post-workshop surveys (see Appendix A). Among the 67 event participants who completed surveys, 52 were healthcare providers or health professions students, 5 were staff or administrators, and 10 were, 
Journal Committed to Social Change on Race and Ethnicity | 2017

community members. Notably, nine of the health professions students in the marriage family therapy and counseling departments were from neighboring universities. Two community members drove from as far as 90 miles away. The following quantitative analyses are from the responses of health care providers, including health professions students.

Only one in three healthcare providers believed they were knowledgeable about the lived experience of sex trafficked victims, opportunities to identify them and provide emergency care, and the prevalence of sex trafficking in Sacramento (see Appendix B). Nearly all of these healthcare providers (96-100\%) indicated that their knowledge in these three areas increased as a result of the workshop. Over half $(51 \%)$ of the healthcare providers were knowledgeable about the physical and mental health issues that may exist for sex trafficking victims, and again, nearly all (98-100\%) indicated that the workshop increased this knowledge (see Appendix B).

Smaller percentages of healthcare providers felt they had the ability to recognize the signs and symptoms of sex trafficked victims' trauma (28.8\%), the ability to provide trauma-sensitive care $(19.2 \%)$, or were confident in their ability to provide healthcare to a sex trafficked victim (21.5\%). Healthcare providers' sense of their ability, or confidence in their ability (self-efficacy) increased for almost all (92-100\%) of these participants.

Fewer than one in five health care providers assessed themselves as knowledgeable about community agencies and resources they could consult with, or whom they could call on to provide emergency services for their sex trafficked patients. 
Journal Committed to Social Change on Race and Ethnicity | 2017

Almost all (98\%) agreed that they had increased in their knowledge of resources outside of the university health system.

This survey also allowed us to assess health care providers' levels of involvement and advocacy in serving this vulnerable sex trafficked patient population. Only 43 participants completed both pre- and post-workshop questions on this survey section. Pre-workshop responses indicate that six out of the $46(13 \%)$ healthcare providers who answered this question indicated they were "active advocates" against sex trafficking (see Appendix C). Following the workshop, 95\% of healthcare providers agreed or strongly agreed that they planned to become advocates against sex trafficking. Despite the large post-workshop differences, these increases were not statistically significant by Chi-square analysis, perhaps because of Type II errors in which the analyses were underpowered to reach statistical significance. Finally, 89\% (51) of all respondents believed that UCDHS had the institutional capacity to identify and help victims of sex trafficking (Data not shown).

\section{Open-Ended Questions}

We grouped responses to the four open-ended questions into thematic categories (see Appendix). We list selected quotes and phrases illustrative of the following themes that emerged, listed here as Education and Training, Community and Institutional Capacity, Awareness and Advocacy, Knowledge of Local Resources, and Coordination of Care.

\section{Themes}

Education and training. At the individual level, healthcare providers indicated the need for training in specific skills such as: initiating the conversation, client/patient 
Journal Committed to Social Change on Race and Ethnicity | 2017

interviewing skills [including] scripted language, building trust, communicating genuine positive regard or compassion for victims, and helping victims without causing more harm. Responses regarding the need for education and training at the organizational level included: educating men, attending physicians, chairs of departments; and incorporating this class into all employees' mandatory classes.

Community and institutional capacity. While some organizational-level suggestions fit into the education and training theme above, participants offered other ideas for building community and institutional capacity that included the following: write new policies and protocols outlining how to assist victims; create an emergency care/crisis facility and provide immediate housing for victims; establish employee giving programs to support local non-profit organizations that provide aid to victims of sex trafficking.

Community awareness and advocacy. Participants felt it was important for UCDHS to enhance community awareness, and participate in advocacy regarding the existence and impact of the local sex trafficking industry. This is illustrated in the following participant responses: advocate for new laws; a community-wide poster that illuminates the problem in Sacramento; sponsor community awareness programs; and include more community members and stakeholders.

Knowledge of local tools and resources. Participants wanted to know who to call when a healthcare provider suspected an individual to be a victim of sex trafficking. They requested specific contact information that could be quickly accessed during the pace of a busy emergency room or clinic. It was recommended that resource 
Journal Committed to Social Change on Race and Ethnicity | 2017

information could be readily available for health providers and staff through the electronic medical record, or by posting protocols on clinic staff room walls.

Coordination of care. Coordination of care among providers of different disciplines, and with those who work for community agencies was a recurring them, illustrated by the following quotes: perceived gaps in collaborative responses among service providers' partnerships with police, schools, and other organizations; attempting to have all healthcare providers on the same page; lack of coordinated response; and changing the mindset of the community, law enforcement, healthcare providers, and family members.

Facilitated dialogue session. The facilitated problem-solving and dialogue session was another opportunity for all participants (law enforcement, community members, UCDHS employees, and students), in both process and content, to witness and learn from the expertise residing within this interprofessional audience, and to experience the collective efficacy that is needed to better serve sex trafficking victims and survivors. One example offered was the recognition of sex trafficking as a community issue that requires everyone, including men, to be involved. Mindset changes among human service professionals were recommended, including the understanding that patients who present with an angry demeanor are victims, and that anger, an adaptive response, is a symptom of deeper trauma.

Another discussion stream illustrated the value and process of gathering together this multi-disciplinary, multi-institutional group of participants from within and outside of UCDHS. A pediatric emergency room physician in the audience related a story of an adolescent male brought in by his parents for being withdrawn following a brief episode 
where he ran away and then returned home. After multiple attempts to connect with this youth, and after several hours of waiting for lab results, the physician was able to elicit a recent incident of sexual abuse by an adult during his brief runaway experience.

The emergency room physician described to the training session participants how helpless she had felt in having gained the young man's trust, only to realize that she did not have the back-up she needed from local law enforcement to affirm this event as a crime against the patient. The law enforcement officer present in the ER declined to initiate a formal criminal case with the attendant examination and documentation. Detective Sydow stated again that not all law enforcement officers agree that persons who have been sex trafficked, or sexually assaulted are "victims." Audience members then asked what UCDHS could do to help Detective Sydow facilitate municipal and county local law enforcement policy, training, and practice changes. Another health professional suggested that we should be able to call Detective Sydow, or another designated skilled and sympathetic officer directly from the emergency room, clinic or inpatient ward, such as a local law enforcement hotline specifically for these tenuous scenarios. In this way, health professionals would be assured of talking with someone who shared the perspective of sex trafficking victims as victims. Yet another participant asked if there was a way to document and communicate reports of these unsatisfactory cases directly back to law enforcement representatives and decision makers, in a feedback loop that the audience did not think currently existed. A UCDHS social worker then reported that she had heard this case in a multidisciplinary feedback session that existed to review UCDHS social work-law enforcement partnerships, especially in regard to domestic violence cases. The 
existence of such a feedback committee was a surprise to many in the audience. What ensued was a real time problem-solving session about the assets of the institution that could have been used (i.e., feedback session) had the physician known about it, and about the strengths, weaknesses, and variability of the support that clinicians currently face if they conscientiously sought disclosure from patients they suspected of being sex trafficked victims. Ms. Albright-Byrd, one of the speakers and a sex trafficking survivor, shared her dream that the UCDHS underwrite an emergency residential facility or longterm safe house specifically for identified and willing sex trafficked patients. The dialogue session of this training exposed challenges and weaknesses of the health system in identifying and then assisting sex trafficked victims. This session becameright there and then—a real-time activity to build UCDHS' capacity to respond to victims' needs by strengthening internal and external interprofessional alliances with the institution.

\section{Discussion}

The goal of the four-hour training session, "Educating UCDHS Healthcare Providers to Identify and Heal Victims of Sacramento's Sex Trafficking" was two-fold. First, it was to inform, equip, inspire, and empower individual clinicians, staff, administrators, and health professions students to actively identify and constructively assist Sacramento's sex trafficked victims who utilize services at the University of California, Davis Health System (UCDHS). Secondly, we sought to assess, demonstrate, and build the institutional capacity of UCDHS to support individual practitioners in their efforts, and to serve the region's victims of sex trafficking in constructive and creative ways. We know of no other studies that emphasize the 
importance and necessity of both an individual practitioner and institution-wide approach, especially within urban academic health systems.

A pre-session survey indicated that only one in three healthcare providers felt they were knowledgeable about the prevalence of sex trafficking in Sacramento, about the lived experience of sex trafficked victims, nor about opportunities to identify them and provide emergency care. Even smaller percentages of healthcare providers felt that they had the ability to recognize the signs and symptoms of sex trafficked victims' trauma $(28.8 \%)$, the ability to provide specifically trauma-sensitive care $(19.2 \%)$, or were confident in their ability to provide healthcare to a sex trafficked victim (21.5\%). Fewer than one in five health care providers assessed themselves as being knowledgeable about community agencies and resources they could consult with, or whom they could call on to provide emergency services for sex trafficked patients.

These percentages are surprisingly low, given that by definition, this is a highly motivated group of self-selected healthcare providers who attended this extended, voluntary training at the end of a workday. This set of pre-session self-assessments is one of this study's most important findings - that this type of training is clearly needed at UCDHS, even among a group of healthcare providers and students already motivated to identify and serve this vulnerable population. We cannot generalize these findings to other urban academic health systems; however, we suspect that UCDHS shares these phenomena with similar health systems across the United States.

Post-survey self-assessments of participants indicate that health professionals and students perceived they increased in awareness of sex trafficking as a local issue, and in knowledge of the lived experience of victims of sex trafficking. Healthcare 
Journal Committed to Social Change on Race and Ethnicity | 2017

professionals and students also believed they experienced increases in their ability to identify signs and symptoms of sex trafficked victims, their ability to provide traumasensitive care to sex trafficked victims, and their confidence in their ability to provide for the healthcare of these vulnerable and traumatized patients. The post-session selfassessments thus indicated provider and students' enhanced self-efficacy, which includes one's belief that one possesses the knowledge and skill to be successful in a task undertaken (Bandura, 1995).

From thematic analysis of participant responses to the open-ended questions on the post-survey, a rich collective expertise emerged. We are able to see together a broad, multi-dimensional picture of the self-assessed needs of individual practitioners as well as their assessments of the needs and the capacity-building potential of the institution. The most prevalent theme ( $41 \%$ of responses, data not shown) in all of the open-ended questions involved expanding education and training delivered to the individual practitioner, staff, or administrator. The majority (95\%) of health care providers and students indicated on the post-survey that they want to become advocates against sex trafficking, compared to $2.3 \%$ who described themselves as advocates before the session. It would be a loss if that passion, as well as individual and collective efficacy, were thwarted if UCDHS focused solely on the training of individuals. Such an unbalanced, individual-level change strategy could fall short, and even frustrate efforts of motivated and newly skilled practitioners without expanding the institutional capacity of UCDHS.

The current literature on training curricula regarding the identification and provision of health care to human-trafficked and sex trafficked victims includes many 
tools and curricula (Ahn et al., 2013). A recent systematic review of educational resources shows that few interventions have been evaluated for their impact on individual trainees beyond immediate, post-session increases in knowledge and awareness. Besides this current study, we know of only one prospectively designed study to measure the impact of an educational intervention on providers (physicians, nurses, and social workers), although our study relied on self-assessments (Grace et al., 2014b). The one-time, educational intervention of up to 60 minutes, delivered to emergency room staff at 20 San Francisco Bay Area hospitals by a physician and a police officer, included background information, local cases, clinical signs, and health implications of human trafficking, along with referral options. Using pre-session and post-session surveys-and a comparison group that did not receive the training in 10 of the emergency rooms-researchers indicate that in the "treatment" group of 10 emergency rooms that staff self-reported increases in knowledge of the topic, of whom to call as resources for potentially identified victims, and an increase in providers who suspected they had served a human-trafficked victim. The comparison group did not experience these increases during the same period of time.

Grace et al. (2014b) noted that their statistically significant findings of selfreported, immediate cognitive outcomes may not change future clinician behavior or patient outcomes. The same is true with the encouraging data of self-assessed impact from our educational intervention. Still, we would argue that making visible this previously invisible patient population, with its unique, often heartrending social complexities, is an important outcome in itself. For instance, before the UCDHS training, only $47 \%$ of health care providers had heard that sex trafficking might be a problem in 
Journal Committed to Social Change on Race and Ethnicity | 2017

Sacramento, but did not know more than that (see Appendix C). Only half (51\%) felt they were familiar with the physical health issues affecting this population, and only $17 \%$ were aware of community resources that they could contact for consultation or emergency care (see Appendix B). This is sobering, again given that this is by definition a highly motivated group of health care providers. Recall that all participants were required to make a written commitment to stay for the entire four-hour session, and participants came from as far as 90 miles away to attend the workshop.

Such interventions can humanize sex trafficked victims, perhaps previously conceptualized as criminals or otherwise stigmatized, and create essential connections between healthcare providers, health system staff, local experts, and community members. The powerful distinction by survivor and expert Leah Albright-Byrd (Bridget's Dream, 2015) is conceptually blockbusting for our audience: "Child prostitution is a misnomer. Children cannot be prostitutes; they can only be rape victims." For some providers, serving minor patients brought in for crimes—crimes often required by their traffickers (i.e., drug possession, petty theft, and prostitution)—this distinction changes everything for them as health care providers, and for their partnerships with law enforcement officials.

Our study has not measured future actions that come from the present expressed intent, or knowledge of participants. Still, in post-session surveys, 95\% of participants stated that they wanted to become advocates against sex trafficking (see Appendix C). (Please note that the term "active advocate" was not further defined for respondents, but we meant it to identify participants who go beyond service provision to work to an end to sex trafficking in our region.) Finally, $89 \%$ of respondents believed 
Journal Committed to Social Change on Race and Ethnicity | 2017

that UCDHS had the institutional capacity to identify and help victims of sex trafficking, an astounding vote of potential collective efficacy (Data not shown).

Perhaps the best way our study serves other urban university health systems is by documenting the potential of educational interventions, not just in informational content, but in process as well. Beyond the education of individuals, the assessment and increasing of institutional capacity—simply via the act of bringing people togetherseemed to build an interprofessional network of UCDHS employees. Building UCDHScommunity connections that individual providers can access assists in moving efforts forward collectively on behalf of these vulnerable patients. The institutional capacitybuilding activity of the facilitated dialogue session exceeded our expectations. The exercise revealed and fulfilled the need to understand one another's roles and skills as well as the need to attach faces and direct contacts to those resources. There is need for porous institutional borders between community and institution, and porous interprofessional borders within the health system. The overall intervention could thus set in motion individual, institutional, and community level developmental processes that can position the urban academic university health system to have a level of impact it might not otherwise have without such a professional convening.

Participant responses ascertained by the post-session surveys represent a wealth of specific ways to improve and build upon this initial extended session. Participants identified skills, tools (i.e., interview scripts with sensitive and trust-building wording), and resources they would need as individuals, and that UCDHS would need as an institution to provide optimal care to sex trafficked patients. Importantly mentioned were institutional constraints (i.e., lack of posted protocols and resources), and 
Journal Committed to Social Change on Race and Ethnicity | 2017

weaknesses in UCDHS/community connections, including the need for more and quickly accessible local law enforcement officials who are sensitive to this issue. Finally, this highly motivated, interprofessional, UCDHS and community audience compiled an extensive list of new, creative ways that UCDHS could make meaningful change in this local health challenge. Next steps mentioned included the creation of interprofessional working groups within UCDHS, and with community groups. To meet the immediate needs of providers, perhaps a larger event could be held on the UC Davis campus, showcasing a broader spectrum of community groups and skilled consultant UCDHS providers who are available to those on the frontline of identifying and caring for this population of patients.

We expect that the lists above will have commonalities with those of other urban academic health systems across the country, but will contain idiosyncrasies as well. For instance, UCDHS, including its health professions schools, is the third largest employer in the Sacramento region, behind only the State of California and the County of Sacramento. This suggests considerable unrealized potential in policy-influencing activities, and the support and expansion of community resources external to UCDHS. In 2012, California State Attorney General Kamala Harris convened a work group of over 80 law enforcement, advocacy, and other community entities. Their work resulted in the groundbreaking, often referenced publication, The State of Human Trafficking in California, 2012 (Harris, 2012). Of the members in the work group, the Alameda County Medical Center in Oakland was the only health system listed, university-associated or otherwise. Other urban academic health systems, in partnership with local, statewide, and federal entities, could enhance efforts to dismantle local sex trafficking industries, 
and to optimally care for this woefully under-served patient population by becoming leaders for increasing awareness and proactive change in their communities.

Several aspects of this work described herein might limit its generalizability to other urban academic health systems. First, while Sacramento is one of the nation's major hubs for sex trafficking, we also have strong organizations, coalitions, and individuals already in place to serve sex trafficked victims and to dismantle the local industry (Syphax, 2012; Taft, 2014; WEAVE, 2015; Sexually Exploited Children and Teens Collaborative, 2015). This means we could offer four hours of dynamic, moving, and locally relevant content, and introduce providers to many advocates and human service providers on the frontlines of this work locally. For example, Leah Albright-Byrd is a Sacramento resident and founder of Bridget's Dream, Inc., a local non-profit that rescues and "restores" sex trafficked victims and offers training nationwide. Ms. Albright-Byrd is a compelling, inspiring, powerful speaker with an amazing story of not just survival, but of "overcoming" [her word]. Not all cities will have such resources.

Participants in this study were a highly motivated group of individuals, many of whom were familiar with this topic. This intervention might be even more impactful for a group of UCDHS employees and students less aware, or passionate about this issue. We have discussed previously how increases in awareness and knowledge do not mean that individuals will change their behavior, or be more clinically effective.

We believe our experience demonstrates the value of an urban academic health center simply convening members of a health system community, and the local community as a profitable starting place to identify, and train highly motivated individuals. This convening can also assist in gathering locally relevant expertise 
regarding the institutional constraints, and opportunities that lie before them. We emphasize that issues of implicit bias in service provision and historical distrust with health, social, and law enforcement institutions are critical elements of excellent service to this hidden population, although we did not specifically address these elements in this introductory training.

\section{Conclusion}

It is an unsettling thought that there are unrecognized sex trafficked victims visiting urban academic health systems in the United States, who are perhaps hoping against hope that a frontline provider, student, or staff member would ask that one question that would identify them as enslaved, or otherwise trapped in an unthinkable situation. Sex trafficking is not only a lucrative phenomenon "over there" in other countries. We have learned that even on the street where UCDHS is located, a local industry thrives largely without our noticing (Syphax, 2012; Taft, 2014). Nationally, over 100,000 minor victims are sex trafficked each year, most from the foster care system. Besides the more obvious immediate physical health issues, long-term mental health issues, including PTSD, depression, and suicidality, manifest in ways that can intergenerationally impact the families, the health of communities, and entire regions.

This is the first study we know of that demonstrates that both individual and institutional capacity can be identified, assessed, and enhanced by gathering an interprofessional group of health system employees, students, and community members to address the health impact of the local sex trafficking industry. Although equipping individual healthcare providers with knowledge and awareness is critical, the training of individuals will likely yield less than it could without enhancing institutional capacity- 
Journal Committed to Social Change on Race and Ethnicity | 2017

building efforts. This includes removing health system constraints that discourage, or limit individual efforts; nurturing community/health system partnerships, and embracing expanded local and statewide practice and policy roles for the academic health center to assist this vulnerable and traumatized patient population, and to join in dismantling the local sex trafficking industry. 


\section{References}

Ahn, R., Alpert, E. J., Purcell, G., Konstantopoulos, W. M., McGahan, A., Cafferty, E., \& Burke, T. F. (2013). Human trafficking: Review of educational resources for health professionals. American Journal of Preventive Medicine, 44(3), 283-289.

Baldwin, S. B., Eisenman, D. P., Sayles, J. N., Ryan, G., \& Chuang, K. S. (2011). Identification of human trafficking victims in health care settings. Health and Human Rights, 13(1), E36-49.

Bandura, A. (1995). Self-efficacy in changing societies. New York, NY: Cambridge University.

Banks, D., \& Kyckelhahn, T. (2011). Trafficking incidents, 2008-2010 (Vol. NCJ 233732), Washington, D.C.: United States Department of Justice.

Barrows, J., \& Finger, R. (2008). Human trafficking and the health care professions. Southern Medical Journal, 101(5), 521-524.

Boyatzis, R. E. (1998). Transforming qualitative information. Thousand Oaks, CA: Sage.

Bridget's Dream. (2013). About us. Retrieved from http://www.bridgetsdream.org/aboutus.html

Clause, K. J., \& Lawler, K. B. (2013). The hidden crime: Human trafficking. South Carolina Nurse, 20(4), 3-5.

Cwikel, J., \& Hoban, E. (2005). Contentious issues in research on trafficked women working in the sex industry: Study design, ethics, and methodology. Journal of Sex Research, 42(4), 306-316.

Diaz, A., Clayton, E., \& Simon, P. (2014). Confronting commercial sexual exploitation and sex trafficking of minors. JAMA Pediatrics, 168(9), 791-792.

Dovydaitis, T. (2010). Human trafficking: The role of the health care provider. Journal of Midwifery and Womens Health, 55(5), 462-467.

Gajic-Veljanoski, O., \& Stewart, D. E. (2007). Women trafficked into prostitution: Determinants, human rights and health needs. Transcultural Psychiatry, 44, 338358.

Grace, A., Ahn, R., \& Konstantapoulos, W. M. (2014a). Integrating curricula on human trafficking into medical education and residency training. JAMA Pediatrics, 168(9), 793-794.

Grace, A., Lippert, S., Collins, K., Pineda, N., Tolani, A., Walker, R., ...Horwitz, S. M. (2014b). Educating health care professionals on human trafficking. Pediatric Emergency Care, 30(12), 856-861.

Gushulak, B., \& MacPherson, D. (2000). Health issues associated with the smuggling and trafficking of migrants. Journal of Immigrant Health, 2(2), 67-78.

Harris, K. (2012). The state of human trafficking in California, 2012. Sacramento: California Department of Justice. Retrieved from http://oag.ca.gov/sites/all/files/pdfs/ht/human-trafficking-2012.pdf.

Hom, K. A. (2013). Trauma and its aftermath for commercially sexually exploited women as told by front-line service providers. Issues In Mental Health Nursing, 34, 75-81.

Hossain, M. (2010). The relationship of trauma to mental disorders among trafficked and sexually exploited girls and women. American Journal of Public Health, 100(12), 2442-2449.

Morse, J. A., \& Field, P. A. (1995). Qualitative research methods for health professionals. Thousand Oaks, CA: Sage. 
Murray-Garcia, J., \& Garcia, J. A. (2008). The institutional context of multicultural education: What is your institutional curriculum. Academic Medicine, 83, 646-652.

Sexually Exploited Children \& Teens Collaborative (SECT). (2015). Retrieved from http://www.sacramentosect.org.

Siskun A., \& Wyler L. S. (2013) Trafficking in persons: U.S. policy and issues for congress. Washington, D.C.: Congressional Research Service.

Squires G \& Kubrin C. (2006). Priviledged places: Race, Opportunity, and uneven development in urban America. Montclair, NJ: National Housing Institute. Retrieved from http://nhi.org/online/issues/147/privilegedplaces.html

Taft I. (2014). FBI's Sacramento office finds nine child sex trafficking victims in region. Sacramento Bee, June 23. Retrieved from http://www.sacbee.com/news/local/crime/article2602104.html

Tervalon M \& Murray-García J. (1998). Cultural Humility versus Cultural Competence: A critical distinction in physician training outcomes. Journal of Healthcare for the Poor and Underserved, 9(2), 117-125.

United Nations News Centre (December 11, 2015). Women in US lagging behind in human rights, UN experts report after 'myth-shattering' visit. Retrieved from http://www.un.org/apps/news/story.asp?NewsID=52797\#.WPIgXBQz7dl

United States Census Bureau, Population Division. (2015). Annual estimates of the resident population for incorporated places of 50,000 or more, July 1, 2014. Retrieved from http://factfinder.census.gov/faces/tableservices/jsf/pages/productview.xhtml?src=b $\mathrm{kmk}$

United States Department of Education. (2013). Human trafficking of children in the United States: A fact sheet for schools, 2013. Retrieved from https://www2.ed.gov/about/offices/list/oese/oshs/tipfactsheet91913.pdf

United States Department of Justice. (2011). Characteristics of suspected human trafficking incidents, 2008-2010. Retrieved from http://www.bjs.gov/index.cfm?ty=pbdetail\&iid=2372

United States Department of State. (2014). Trafficking in persons report, 2014. Retrieved from http://www.state.gov/g/tip/rls/tiprpt/2012

University of California, Davis Medical Center. (2015). About the health system. Facts and figures. Retrieved from http://www.ucdmc.ucdavis.edu/leadership/facts_figures.html

WEAVE, Inc. (Women Escaping A Violent Environment). (n.d.). Retrieved from http://www.weaveinc.org.

Zimmerman, C., Kiss, L., Hossain, M., Mazeda, H., \& Watts, C. (2009). Trafficking in persons: A health concern. Ciência \& Saúde Coletiva, 14(4), 1029-1035.

Zimmerman, C., Hossain, M., Yun, K., Gajdadziev, V., Guzun, N., Tchomarova, M., \& Watts, C. (2008). The health of trafficked women: A survey of women entering post-trafficking services in Europe. American Journal of Public Health, 98(1), 5559. 
Journal Committed to Social Change on Race and Ethnicity | 2017

Appendix A

Characteristics of Health Care Providers and of Staff, Administrators and Community

\begin{tabular}{|c|c|c|}
\hline Characteristics & $\begin{array}{l}\text { Health Care Providers } \\
(\mathrm{N}=52)\end{array}$ & $\begin{array}{r}\text { Staff, Administrators \& } \\
\text { Community }(\mathrm{N}=15)\end{array}$ \\
\hline Consent & $52(100 \%)$ & $15(100 \%)$ \\
\hline \multicolumn{3}{|l|}{ UCDHS employee } \\
\hline Yes & $23(44.2 \%)$ & $4(26.7 \%)$ \\
\hline No & $29(55.8 \%)$ & $11(73.3 \%)$ \\
\hline \multicolumn{3}{|l|}{ UC Davis student } \\
\hline Yes & $19(36.5 \%)$ & $3(20.0 \%)$ \\
\hline No & $33(63.5 \%)$ & $12(80.0 \%)$ \\
\hline \multicolumn{3}{|l|}{$\begin{array}{l}\text { Type of Healthcare Provider } \\
\text { or Student }\end{array}$} \\
\hline Faculty & $4(7.7 \%)$ & --- \\
\hline Physician & $14(26.9 \%)$ & --- \\
\hline Registered Nurse & $13(25.0 \%)$ & --- \\
\hline Nurse Practitioner & $2(3.8 \%)$ & --- \\
\hline Physician Assistant & $1(1.9 \%)$ & --- \\
\hline Public Health & $3(5.8 \%)$ & --- \\
\hline Post-Doctoral & $3(5.8 \%)$ & --- \\
\hline Masters Leadership & $1(1.9 \%)$ & --- \\
\hline $\begin{array}{l}\text { Other (6 marriage family } \\
\text { therapist students, } 3 \\
\text { graduate counseling } \\
\text { students, } 2 \text { medical } \\
\text { students, } 1 \text { chaplain, and } \\
1 \text { other provider } \\
\text { unspecified) }\end{array}$ & $13(21.2 \%)$ & --- \\
\hline
\end{tabular}




\section{Appendix B}

Pre- and Post-Workshop Self-Assessments of Healthcare Providers' Capacity to Serve Sex trafficked Patients

\begin{tabular}{|c|c|c|}
\hline Questions & $\begin{array}{l}\text { Pre-Event, Participants } \\
\text { Who Agreed or } \\
\text { Strongly Agreed } \\
\mathrm{n}(\%)\end{array}$ & $\begin{array}{c}\text { Post-Event, } \\
\text { Participants Who Agreed or } \\
\text { Strongly Agreed They } \\
\text { Increased In This } \\
\text { Category } \\
\mathrm{n}(\%) \\
\end{array}$ \\
\hline $\begin{array}{l}\text { I am knowledgeable about the lived } \\
\text { experiences of sex trafficked victims } \\
\text { and survivors. }\end{array}$ & $15(29.4 \%)$ & $51(100 \%)$ \\
\hline $\begin{array}{l}\text { I am knowledgeable about opportunities } \\
\text { for health care providers to identify } \\
\text { and provide emergency care for } \\
\text { victims of sex trafficking. }\end{array}$ & $16(31.4 \%)$ & $50(98.1 \%)$ \\
\hline $\begin{array}{c}\text { I am knowledgeable about the prevalence } \\
\text { of sex trafficking in Sacramento. }\end{array}$ & $18(35.3 \%)$ & $49(96.1 \%)$ \\
\hline $\begin{array}{l}\text { I have the ability to recognize the signs } \\
\text { and symptoms of the impact of } \\
\text { trauma on my patients who are } \\
\text { victims of sex trafficking. }\end{array}$ & 15 (28.8\%) & $51(100 \%)$ \\
\hline $\begin{array}{l}\text { I am knowledgeable about significant } \\
\text { physical health issues that may } \\
\text { exist for sex trafficked victims. }\end{array}$ & $26(51 \%)$ & 50 (98.1\%) \\
\hline $\begin{array}{l}\text { I am knowledgeable about significant } \\
\text { mental/emotional health issues that } \\
\text { may exist for sex trafficking victims. }\end{array}$ & $29(55.7 \%)$ & $50(100 \%)$ \\
\hline $\begin{array}{l}\text { I am knowledgeable about individual } \\
\text { community agencies and resources } \\
\text { whom I can contact for consultation } \\
\text { and emergency care for victims of } \\
\text { sex trafficking. }\end{array}$ & $9(17.6 \%)$ & $50(98.1 \%)$ \\
\hline $\begin{array}{l}\text { I have the ability to provide trauma- } \\
\text { sensitive care to victims and } \\
\text { survivors of sex trafficking. }\end{array}$ & $10(19.2 \%)$ & 47 (92.2\%) \\
\hline $\begin{array}{l}\text { I am confident in my ability to provide } \\
\text { healthcare to a victim of sex } \\
\text { trafficking }\end{array}$ & $11(21.5 \%)$ & $49(96.1 \%)$ \\
\hline
\end{tabular}

None of these post-workshop changes was statistically significant, presumably because of Type II errors in which the small number of respondents meant the study was underpowered to detect statistical significance. 
Journal Committed to Social Change on Race and Ethnicity | 2017

\section{Appendix C}

Pre- and Post-Workshop Levels of Awareness of and Active Advocacy on Behalf of Local Sex trafficked Victims

\begin{tabular}{|c|c|c|c|c|c|}
\hline & $\begin{array}{l}\# 1 \\
\text { I am not at all } \\
\text { aware of sex } \\
\text { trafficking. } \\
\mathrm{n}(\%)\end{array}$ & $\begin{array}{l}\text { \#2 } \\
\text { I have heard sex } \\
\text { trafficking may be a } \\
\text { problem, but I do not } \\
\text { know more than that. } \\
\mathrm{n}(\%)\end{array}$ & $\begin{array}{l}\# 3 \\
\text { I know the details about } \\
\text { Sacramento's sex } \\
\text { trafficking, but I am } \\
\text { neither an active } \\
\text { advocate nor am I trained } \\
\text { in identification. } \\
\mathrm{n}(\%)\end{array}$ & $\begin{array}{l}\# 4 \\
\text { I am an active advocate } \\
\text { against sex trafficking but I } \\
\text { do not have training in } \\
\text { identification. } \\
\mathrm{n}(\%)\end{array}$ & $\begin{array}{l}\# 5 \\
\text { I am an active advocate } \\
\text { and trained in } \\
\text { identification and } \\
\text { treatment of sex } \\
\text { trafficked victims } \\
\mathrm{n}(\%)\end{array}$ \\
\hline $\begin{array}{l}\text { Healthcare } \\
\text { Providers } \\
(\mathrm{N}=43), \\
\text { Pre-Workshop }\end{array}$ & $1(2.3)$ & $20(46.5 \%)$ & $16(37.2 \%)$ & $5(11.6)$ & $1(2.3)$ \\
\hline \multicolumn{4}{|c|}{$\begin{array}{l}\text { Pre-Workshop } \\
\text { "I am an active advocate..."* }\end{array}$} & \multicolumn{2}{|c|}{$6(14 \%)$} \\
\hline \multicolumn{4}{|c|}{$\begin{array}{l}\text { Post-Workshop Active Advocates } \\
\text { "After the workshop, I plan to become an active advocate against sex trafficking." }\end{array}$} & \multicolumn{2}{|c|}{$41(95.3 \%)$} \\
\hline
\end{tabular}

${ }^{*}$ Combined percentage of the two cells above this one, \#4 and \#5. 
APPENDIX. Educating UCDMC Healthcare Providers To Identify and Heal Victims of Sacramento's Sex-Trafficking Industry

Healthcare Provider Pre \& Post Educational Event Survey

1. I understand that by completing this survey I give my consent to participate.

YES NO

2. Do you work for the University of California Davis Medical Center?

YES NO

3. Are you a student of University of California Davis?
YES
NO

4. Please circle type of healthcare provider or student that applies to you (may circle more than one):
a. Faculty
d. Nurse Practitioner
g. Post-Doctoral
b. Physician
e. Physician's Assistant
h. Master's Leadership
c. Registered Nurse
f. Public Health
i. PhD Leadership
j. Other (Specify)

5. Did you read Half The Sky and/or participate in any of the Half The Sky Book Club Events?

6. Please circle the answer that best describes you. Answer should describe your state if knowledge of sex trafficking in Sacramento before this year's lectures and Inter-professional Book Club events featuring the book, Half The Sky, if you attended any of these lectures and book club events.

\begin{tabular}{|l|l|l|l|l|}
\hline $\begin{array}{l}\text { I am an active advocate and } \\
\text { trained in identification and } \\
\text { treatment of sex trafficked } \\
\text { victims. }\end{array}$ & $\begin{array}{l}\text { I am an active advocate } \\
\text { against sex trafficking } \\
\text { but I do not have } \\
\text { training in } \\
\text { identification. }\end{array}$ & $\begin{array}{l}\text { I know the details about } \\
\text { Sacramento's sex trafficking, } \\
\text { but I am neither an active } \\
\text { advocate nor am I trained in } \\
\text { identification. }\end{array}$ & $\begin{array}{l}\text { I have heard sex- } \\
\text { trafficking may be a } \\
\text { problem, but I do not } \\
\text { know more than that. }\end{array}$ & $\begin{array}{l}\text { I am not at all } \\
\text { trafficking. }\end{array}$ \\
\hline
\end{tabular}

Healthcare Provider Pre-Educational Event Survey

7. I am knowledgeable about the lived experiences of sex-trafficking victims and survivors.

8. I am knowledgeable about opportunities for healthcare providers to identify and provide emergency care for victims of sex-trafficking.

9. I am knowledgeable about the prevalence of sextrafficking in Sacramento.

10. I have the ability to recognize signs and symptoms of the impact of trauma on my patients who are victims of sex-trafficking.

11. I am knowledgeable about significant physical health issues that may exist for sex-trafficking victims.

12. I am knowledgeable about significant mental/emotional health issues that may exist for sex-trafficking victims.

13. I am knowledgeable about individual community agencies and resources whom I can contact for consultation and emergency care for victims of sextrafficking.

14. I have the ability to provide trauma-sensitive care to victims and survivors of sex-trafficking.

15. I am confident in my ability to provide healthcare to a victim or survivor of sex-trafficking.

PLEASE SEE REVERSE SIDE

\begin{tabular}{|c|c|c|c|c|}
\hline $\begin{array}{l}\text { Strongly Agree } \\
4\end{array}$ & $\begin{array}{l}\text { Agree } \\
3\end{array}$ & $\begin{array}{l}\text { Disagree } \\
2\end{array}$ & $\begin{array}{l}\text { Strongly Disagree } \\
1\end{array}$ & $\mathrm{~N} / \mathrm{A}$ \\
\hline $\begin{array}{l}\text { Strongly Agree } \\
4\end{array}$ & $\begin{array}{l}\text { Agree } \\
3\end{array}$ & $\begin{array}{l}\text { Disagree } \\
2\end{array}$ & $\begin{array}{l}\text { Strongly Disagree } \\
1\end{array}$ & $\mathrm{~N} / \mathrm{A}$ \\
\hline $\begin{array}{l}\text { Strongly Agree } \\
4\end{array}$ & $\begin{array}{l}\text { Agree } \\
3\end{array}$ & $\begin{array}{l}\text { Disagree } \\
2\end{array}$ & $\begin{array}{l}\text { Strongly Disagree } \\
1\end{array}$ & $\mathrm{~N} / \mathrm{A}$ \\
\hline $\begin{array}{l}\text { Strongly Agree } \\
4\end{array}$ & $\begin{array}{l}\text { Agree } \\
3\end{array}$ & $\begin{array}{l}\text { Disagree } \\
2\end{array}$ & $\begin{array}{l}\text { Strongly Disagree } \\
1\end{array}$ & N/A \\
\hline $\begin{array}{l}\text { Strongly Agree } \\
4\end{array}$ & $\begin{array}{l}\text { Agree } \\
3\end{array}$ & $\begin{array}{l}\text { Disagree } \\
2\end{array}$ & $\begin{array}{l}\text { Strongly Disagree } \\
1\end{array}$ & $\mathrm{~N} / \mathrm{A}$ \\
\hline $\begin{array}{l}\text { Strongly Agree } \\
4\end{array}$ & $\begin{array}{l}\text { Agree } \\
3\end{array}$ & $\begin{array}{l}\text { Disagree } \\
2\end{array}$ & $\begin{array}{l}\text { Strongly Disagree } \\
1\end{array}$ & $\mathrm{~N} / \mathrm{A}$ \\
\hline $\begin{array}{l}\text { Strongly Agree } \\
4\end{array}$ & $\begin{array}{l}\text { Agree } \\
3\end{array}$ & $\begin{array}{l}\text { Disagree } \\
2\end{array}$ & $\begin{array}{l}\text { Strongly Disagree } \\
1\end{array}$ & $\mathrm{~N} / \mathrm{A}$ \\
\hline $\begin{array}{l}\text { Strongly Agree } \\
4\end{array}$ & $\begin{array}{l}\text { Agree } \\
3\end{array}$ & $\begin{array}{l}\text { Disagree } \\
2\end{array}$ & $\begin{array}{l}\text { Strongly Disagree } \\
1\end{array}$ & $\mathrm{~N} / \mathrm{A}$ \\
\hline $\begin{array}{l}\text { Strongly Agree } \\
4\end{array}$ & $\begin{array}{l}\text { Agree } \\
3\end{array}$ & $\begin{array}{l}\text { Disagree } \\
2\end{array}$ & $\begin{array}{l}\text { Strongly Disagree } \\
1\end{array}$ & $\mathrm{~N} / \mathrm{A}$ \\
\hline
\end{tabular}

SEE REVERSE SIDE FOR POST EDUCATIONAL SURVEY 